\title{
HISTOPATHOLOGICAL STUDY ON ASTROCYTE IN VARIOUS LIVER DISEASES PART I
}

\author{
HIDEKI KIDA \\ First Department of Pathology, Kurume University School of Medicine, \\ Kurume, 830, Japan \\ SHIGEMI ANRAKU \\ Institute of Brain Diseases, Kurume University School of Medicine, \\ Kurume, 830, Japan
}

Received for publication February 15, 1979

I. A comparative study of liver findings and astrocyte

In cases of Wilson's disease, occurence of Alzheimer glia type I, type II (Hösslin and Alzheimer ; 1912) and Opalski cell (Opalski ; 1930) are known as the characteristic histopathological findings in the brain. However, it was proved that only Alzheimer glia type II was found in various liver diseases as well as Wilson's disease by some investigators (Scherer ; 1933, Stadler ; 1936, Marui ; 1936, Omaru ; 1941, Nomura ; 1959, Harada ; 1961, etc.).

Stadler (1936) classified Alzheimer glia type II into three grades. We compared statistically liver findings with histological changes of astrocyte.

57 autopsy cases of liver disease. in which certain histological changes were recognized, (except for Wilson's disease), were studied and 14 cases without liver disease were studied as a control. These 71 cases were fixed with $10 \%$ formalin solution. Tissues were obtained from frontal lobe, occipital lobe, corpus striatum and cerebellum, and $\mathrm{H}-\mathrm{E}$ and Nissl stains were done.

In most of the 71 cases, Alzheimer glia type II was found, but Alzheimer glia type I and Opalski cell were not. Alzheimer glia type II was classified into three grades according to Stadler's grading (Table 1). Grade of Alzheimer glia type II was differed from part to

TABLE 1

Grading of Alzheimer glia type II (Stadler)

\begin{tabular}{c|c|c|c|c}
\hline Grade & Diameter & Chromatin & Shape & Nuclear membrane \\
\hline Grade I & $\begin{array}{c}10-15 \mu \\
(2 \text { times of normal })\end{array}$ & slight diminution & round & normal thickness \\
\hline Grade II & $15-20 \mu$ & sparse & round - oval & focally thickened \\
\hline Grade III & $\begin{array}{c}20 \mu- \\
\text { over } 3 \text { times } \\
\text { of normal })\end{array}$ & sparse vesicular & irregular & thin \\
\hline
\end{tabular}


TABLE 2

Distribution of Alzheimer glia type II

\begin{tabular}{c|c|c|c|c|c}
\hline Grade & Location & Frontal lobe & Occipital lobe & $\begin{array}{c}\text { Corpus } \\
\text { striatum }\end{array}$ & $\begin{array}{c}\text { Dentate } \\
\text { nuclei }\end{array}$ \\
\hline Grade I & 19 & 10 & 11 & 16 & 10 \\
Grade II & 23 & 7 & 2 & 14 & 12 \\
Grade III & 7 & 0 & 1 & 4 & 4 \\
\hline Total & 49 & 17 & 14 & 34 & 26 \\
\hline
\end{tabular}

TABLE 3

Frequency and grade of Alzheimer glia type II

\begin{tabular}{|c|c|c|c|c|c|c|}
\hline & & Case & Normal & $\underset{\mathrm{I}}{\text { Grade }}$ & Grade & Grade \\
\hline \multirow{13}{*}{$\begin{array}{l}\text { Liver } \\
\text { disease }\end{array}$} & Congestive liver (slight) & 7 & 4 & 3 & 0 & 0 \\
\hline & Fatty liver & 3 & 1 & 1 & 1 & 0 \\
\hline & Metastatic tumor & 6 & 1 & 3 & 2 & 0 \\
\hline & Hepatocellular carcinoma & 1 & 0 & 1 & 0 & 0 \\
\hline & Acute hepatic necrosis & 5 & 0 & 3 & 2 & 0 \\
\hline & Liver fibrosis & 4 & 0 & 2 & 1 & 1 \\
\hline & Liver cirrhosis type A & 4 & 0 & 0 & 3 & 1 \\
\hline & $\begin{array}{l}\text { Liver cirrhosis type A } \\
\text { with hepatocellular carcinoma }\end{array}$ & 11 & 0 & 3 & 8 & 0 \\
\hline & Liver cirrhosis type B & 4 & 0 & 0 & 1 & 3 \\
\hline & $\begin{array}{l}\text { Liver cirrhosis type B } \\
\text { with hepatocellular carcinoma }\end{array}$ & 2 & 0 & 1 & 0 & 1 \\
\hline & Portal circulatory abnormality & 1 & 0 & 0 & 0 & 1 \\
\hline & Others & 9 & 2 & 2 & 5 & 0 \\
\hline & Total ( ) $\%$ & 57 & $8(14)$ & $19(33.3)$ & $23(40.4)$ & $7(12.3)$ \\
\hline \multirow{5}{*}{ Control } & Acute encephalopathy & 1 & 1 & 0 & 0 & 0 \\
\hline & Paretic dementia & 3 & 3 & 0 & 0 & 0 \\
\hline & Motor neuron disease & 2 & 1 & 1 & 0 & 0 \\
\hline & Renal failure & 8 & 4 & 3 & 1 & 0 \\
\hline & Total ( ) \% & 14 & $9 \quad(64.3)$ & $4 \quad(28.6)$ & $1(7.1)$ & 0 \\
\hline
\end{tabular}

* A-II : Alzheimer glia type II. 
part in most cases, therefore the decision of grading depended on the cells showing stronger degeneration.

In most cases, Alzheimer glia type II was remarkably seen in corpus striatum and dentate nuclei with a significant difference of that in cerebral cortex $(\mathrm{P}<0.01)$ as shown Table 2 . In concern to grading of Alzheimer glia type II in various portions, no significant difference was observed. Alzheimer glia type II in spinal cord was recognized in only one case among the 7 cases of liver disease.

Frequency and grade of Alzheimer glia type II in the 71 cases are shown in Table 3. Alzheimer glia type II was found in 49 cases out of 57 cases of liver disease (86\%), and in 5 cases among 14 control cases (36\%). Statistically, a significant difference was seen between the group of liver diseases and control $(\mathrm{P}<0.01)$. Alzheimer glia type II was seen in all cases of hepatocellular carcinoma, acute hepatic necrosis, liver fibrosis, liver cirrhosis and portal circulatory abnormality. In concern to grading of Alzheimer glia type II, statistically, a significant difference was seen between liver disease and control $(\mathrm{P}<0.01)$. Among the liver diseases, grade III of Alzheimer glia type II was found in the case of portal circulatory abnormality, liver fibrosis and liver cirrhosis.

Stastically, a significant difference of grading of Alzheimer glia type II was seen between liver cirrhosis type $A$ and type $B(P<0.05)$, as shown in Table 4. Type A was superior to Type B.

Alzheimer glia type II was found in 5 cases among the 6 cases of metastatic tumor of the liver, and in all cases among the 14 cases of hepatocellular carcinoma. However, in concern to grading of Alzheimer glia type II, statistically, no significant difference was seen between both group as shown in Table 5 .

There was no close relationship between the size of hepatic tumor and the grading and frequency of Alzheimer glia type II, and also between spleen weight in the cases of liver disease and frequency and grading of Alzheimer glia type II.

Furthermore, no relationship was seen between esophageal varices and

TABLE 4

Grading of Alzheimer glia type II in the cases of liver cirrhosis

\begin{tabular}{l|c|c|c|c|c}
\hline & Case A-I & Normal & Grade I & Grade II & Grade III \\
\hline Liver cirrhosis type A & 6 & 0 & 1 & 1 & 4 \\
\hline Liver cirrhosis type B & 15 & 0 & 3 & 11 & 1 \\
\hline
\end{tabular}

$\mathrm{x}^{2}=8.91, \quad \mathrm{df}=2, \quad \mathrm{P}<0.05$.

TABLE 5

Grading of Alzheimer glia type II in the cases of liver tumor

\begin{tabular}{l|c|c|c|c|c}
\hline & Case A-II & Normal & Grade I & Grade II & Grade III \\
\hline Metastatic tumor & 6 & 1 & 3 & 2 & 0 \\
\hline Hepatocellular carcinoma & 14 & 0 & 5 & 8 & 1 \\
\hline
\end{tabular}

$x^{2}=3.45, \quad d f=3, \quad P>0.05$. 
Alzheimer glia type II.

\section{A comparative study of clinical} findings and astrocyte

In Japan, there are a few papers, in which clinical findings and astrocyte were comparatively studied (Watanabe ; 1960, Harada ; 1961).
In concern to frequency of Alzheimer glia type II , statistically, a significant difference was seen between the cases with disturbance of consciousness and the cases without it $(\mathrm{P}<0.05)$, as shown in Table 6. Furthermore, the same might be said of the grading ( $P$ $<0.05)$, as shown in Table 6 .

TABLE 6

Frequency and grade of Alzheimer glia type II

\begin{tabular}{c|c|c|c|c|c}
\hline A-II & Normal & Grade I & Grade II & Grade III & Total \\
\hline $\begin{array}{c}\text { With consciousness } \\
\text { disturbance }\end{array}$ & 2 & 10 & 15 & 6 & 33 \\
\hline $\begin{array}{c}\text { Without consciousness } \\
\text { disturbance }\end{array}$ & 5 & 5 & 6 & 0 & 16 \\
\hline & $\begin{array}{l}\mathrm{x}^{2}=5.58, \quad \mathrm{df}=1, \quad \mathrm{P}<0.05 \\
\mathrm{x}^{2}=7.86, \quad \mathrm{df}=3, \quad \mathrm{P}<0.05\end{array}$
\end{tabular}

In concern to frequency and grading of Alzheimer glia type II, statistically, no significant difference was seen between the cases with a disturbance of consciousness over one week and the cases within a week. However, grade III Alzheimer glia type II was found in the cases with a disturbance of consciousness over two weeks, and it seemed that there was relationship between the period of the consciousness disturbance and the grading of Alzheimer glia type II.

Statistically, no significant difference of frequency and grading of Alzheimer glia type II was seen between the cases with repeated disturbance of consciousness and the cases without it. However, 5 cases among the 6 cases with grade III Alzheimer glia type II repeated disturbance of consciousness, and it seemed that there was relationship between the repeated consciousness disturbance and the grading of Alzheimer glia type II.

Comparison of serum ammonia, frequency and grading of Alzheimer glia type II, abnormal high level of ammonia was seen in all cases with grade III Alzheimer glia type II as shown in Table 7. It seemed that high ammonia level tended to run parallel with fre-

TABLE 7

Frequency and grade of Alzheimer glia type II

\begin{tabular}{c|c|c|c|c|c}
\hline A-II & Normal & Grade I & Grade II & Grade III & Total \\
\hline $\begin{array}{c}\text { Abnormal ammonia } \\
\text { high level }\end{array}$ & 0 & 6 & 7 & 5 & 18 \\
\hline $\begin{array}{c}\text { Normal ammonia } \\
\text { level }\end{array}$ & 1 & 5 & 3 & 0 & 9 \\
\hline
\end{tabular}


quency and grading of Alzheimer glia type II. Statisically, however, no significant differrence of frequency and grading of Alzheimer glia type II was recognized between the cases with high ammonia level and the cases with normal ammonia level. There was no relationship between blood urea nitrogen (BUN) and frequency and grading of Alzheimer glia type II, and also between serum glutamic pyruvic transaminase (GPT) and frequency and grading.

Alzheimer glia type II was found in 11 cases among the 12 cases with high abnormal level of bromsulfalein test (BSP) and indocyanine green test (ICG)
(91.6\%), but, 2 cases showed normal level of ICG. All cases with grade III Alzheimer glia type II showed abnormal high level of BSP and ICG.

Although, statistic study could not be applied because of small number of the cases, it seemed that there was close relationship between BSP, ICG and Alzheimer glia type II, as shown in Table 8.

However, in order to conclude the existence of a causal relationship between clinico-biochemical result, such as BSP, ICG, and ammonia, and Alzheimer glia type II, furtherstudy by accumulation of the cases should be needed.

TABLE 8

Frequency and grade of Alzheimer glia type II

\begin{tabular}{c|c|c|c|c|c}
\hline A-II & Normal & Grade I & Grade II & Grade III & Total \\
\hline $\begin{array}{c}\text { Abnormal BSP or } \\
\text { ICG high level }\end{array}$ & 1 & 2 & 5 & 4 & 12 \\
\hline $\begin{array}{c}\text { Normal BSP or ICG } \\
\text { level }\end{array}$ & 0 & 0 & 2 & 0 & 2 \\
\hline
\end{tabular}

\section{REFERENCES}

HARADA, K. (1961). Zur Histopathologie des Gehirns bei Leberkrankheiten. Brain Nerve. 13, 514-524.

Hösslin, C. V. and Alzheimer, A. (1912).

Ein Beitrag zur Klinik und pathologischen Anatomie der Westphal Strümpellschen Pseudosklerose. Z. ges. Neurol. Psychiat. 8, 183-209.

MARUi, T. (1936). Histopathological study of the brain in various liver diseases. Tohoku med. J. 21, 455-471 (in Japanese).

Nomura, H. (1959). Histopathological study of the brain in liver diseases. Yokohama med. J. 9, 349-368 (in Japanese).

OMARU, I. (1941). The changes of central nervous system in liver diseases. Fukuoka Acta med. 34, 208-236 (in Japanese).
OpALski, A. (1930). Über eine besondere Art von Gliazellen bei der Wilson-Pseudosklerosegruppe. Z. ges. Neurol. Psychiat. 124, 420-425.

Scherer, H. J. (1933). Zur Frag der Beziehungen zuwischen Leber- und Gehirnveränderungen. Virchows Arch. 288, 333-345.

STADLER, H. (1936). Histopathologische Unter suchungen zur Frage der Beziehung zwischen Leber-und Gehirn-veränderungen. Z . ges. Neurol. Psychiat. 154, 626-657.

Watanabe, H. (1960). Studies of hepatocerebral disease ; the relationship of hepatolenticular degeneration, a specific form of hepatocerebral degeneration, hepatocerebral syndrome due to schistosomiasis japonica chronica, and terminal hepatic coma. Psychiat. Neurol. jap. 62, 235-264. 